\title{
Ni(II) REMOVAL BY BIOSORPTION USING FICUS RELIGIOSA (PEEPAL) LEAVES
}

\author{
MUHAMMAD ZAHEER ASLAM, NAVEED RAMZAN*,SHAHID NAVEED, NADEEM FEROZE
}

Department of Chemical Engineering, University of Engineering \& Technology, Lahore (54890)- Pakistan

(Received: May 7, 2009 - Accepted: December 24, 2009)

\begin{abstract}
The pollutant binding capacity of acid treated Ficus Religiosa (Peepal) leaves was investigated in a batch system under varying conditions. The results indicate that sorption equilibrium was established in about 60 minutes with equilibrium capacity of $6.35 \pm 0.54 \mathrm{mg} / \mathrm{g}$. The Ni(II) sorption is highly dependent on $\mathrm{pH}$ and maximum removal was observed at $\mathrm{pH} 7$ above which metal started to precipitate. It was also observed that sorption of $\mathrm{Ni}(\mathrm{II})$ decreases with increase in temperature. The experimental results were analyzed in terms of Langmuir and Freundlich isotherms. The Freundlich isotherm model fitted well to data with 0.94 regression co-efficient $\left(\mathrm{R}^{2}\right)$. Evaluation of experimental data in terms of biosorption kinetics showed that the biosorption of nickel (II) on biomass followed pseudosecond order kinetics. The results showed that biosorbent is an attractive low cost alternative for the treatment of wastewaters containing lower concentrations of Nickel.
\end{abstract}

Keywords: Ficus Religiosa, Nickel, Biosorption, Metal removal, Isotherm models.

\section{INTRODUCTION}

Rapid industrialization has led to increased discharge of chemicals, that causes environmental and public health problems. The noteworthy group of toxic chemicals is heavy metals with high toxicity that pose a serious threat to biolife and environment ${ }^{1}$. The heavy metals concern increases due to their bioaccumulation tendency and persistency in nature ${ }^{2}$. Conventional techniques for removal of metal ions from aqueous solutions include chemical precipitation, ion-exchange, chemical oxidation/reduction, membrane technologies and adsorption. But these methods may be ineffective and/or extremely expensive for low concentrations in the range $1-100 \mathrm{mg} \mathrm{L}^{-1}$. Moreover, major drawback of these conventional treatments is the production of toxic chemical sludge and their disposal problems that involve much cost and are not eco-friendly as well. Therefore, the removal of toxic heavy metals is of great importance and requires the reduction of heavy metals to a safe limit in cost effective and environmental friendly manner ${ }^{3-5}$.

Biosorption has emerged as an alternative solution for the removal of toxic metals from water/wastewater ${ }^{6}$. It can be considered as collective term for a number of passive, metabolism independent accumulation processes and may include chemical and/or physical adsorption, precipitation, ion exchange, complexation and chelation ${ }^{2}$. The major advantages of biosorption over the conventional methods are its low operating cost, reduction of chemical or biological sludge to be disposed of and high efficiency in detoxitifying very dilute effluents and no nutrient requirements. This removal process is fast; it takes only a few minutes and takes place under normal pressure and temperature conditions. However, there are a limited number of treatment plants using biosorption/bioaccumulation-based processes.

$\mathrm{Ni}(\mathrm{II})$ is a known environmental pollutant and its removal is of major concern because nickel compounds are carcinogenic and also can cause asthma. Another common adverse health effect of $\mathrm{Ni}(\mathrm{II})$ is skin allergy. Nickel is released into the atmosphere during nickel mining and by industries that make or use nickel, nickel alloys, or nickel compounds. Such as mineral processing, non-ferrous metal, paint formulation, electroplating, porcelain enameling, and copper sulphate manufacture. Nickel is also released into the atmosphere by oil-burning power plants, coal-burning power plants, and trash incinerators. Nickel ion concentration in different industrial effluents depends on the metal intensification in the process and type of industry. While the nickel(II) ion concentration in plating rinse can approach 2-900 $\mathrm{mg} \mathrm{L}^{-1}$, wastewater from porcelain enamelling, paint and ink formulation and copper sulphate manufacture industries record effluent nickel(II) ion concentrations varying over $0.25-67,0-40$, and around $22 \mathrm{mg} \mathrm{L}^{-17}$. Environmental Protection Agency (EPA) has set the maximum discharge limits ${ }^{8}$ for Nickel in wastewater as $2-3 \mathrm{mg} \mathrm{L}^{-1}$.

Abundant materials have been suggested as a potential biosorbent for heavy metals. In recent years, numerous low cost agricultural waste materials have been proposed as potential biosorbents. These include tea waste and coffee, hazelnut shells, peat, moss, leaf mould, sea weeds, coconut husk, bagasse, rice hulls, modified cellulosic materials, peanut skins, algae, bark, modified bark, plants biomass and bituminous coal ${ }^{9-14}$. The research work presented herein is a part of the investigations conducted to evaluate the effectiveness of low cost adsorbent material viz. Ficus Religiosa (Peepal) leaves in Pakistan. Various parameters like contact time, temperature, initial $\mathrm{pH}$ of the solution and initial metal concentration were investigated using batch studies.

\section{MATERIALS AND METHODS}

\section{Reagents}

All the chemicals used in the present study were of analytical grade. These chemicals include $\mathrm{NiSO}_{4} \cdot 6 \mathrm{H}_{2} \mathrm{O}$ (Merck), $0.1 \mathrm{~mol} \mathrm{~L}^{-1} \mathrm{NaOH}, 0.1 \mathrm{~mol} \mathrm{~L}^{-1} \mathrm{H}_{2} \mathrm{SO}_{4}$ and $\mathrm{Ni}$ (II) atomic absorption spectrometry standard solution $\left(1000 \mathrm{mg} \mathrm{L}^{-1}\right)$ (Fluka Chemicals)

\section{Preparation of Biosorbent}

Leaves were collected and washed with tap water and then dried in shadow. Dried leaves were ground and sieved to 50 mesh sizes. $50 \mathrm{~g}$ leaves powder was soaked in 1 liter, $0.1 \mathrm{~mol} \mathrm{~L}^{-1} \mathrm{HNO}_{3}$, solution for $24 \mathrm{hr}$ to precipitate out already adsorbed metals on the biomass surface from the environment. It was then filtered and washed with distilled water to remove acid contents. Washing was continued till the $\mathrm{pH}$ of filtrate became neutral. And filter cake was first dried at room temperature and then in an oven at $105^{\circ} \mathrm{C}$ to constant weight. No other chemical and/or physical treatments were used prior to biosorption experiments. The biomass was then stored in air tight glass bottles to protect it from moisture. Fourier Transform infrared (FTIR) spectroscopic studies indicates the presence of hydroxyl, carboxylic, carbonyl, amino and nitro groups in the leaves which are important sites for metal sorption ${ }^{10}$.

\section{Preparation and analysis of $\mathrm{Ni}$ (II) Solution}

For biosorption experiments, stock nickel solution of $1000 \mathrm{mg} \mathrm{L}^{-1}$ was prepared by dissolving an appropriate amount of nickel salt $\left(\mathrm{NiSO}_{4} \cdot 6 \mathrm{H}_{2} \mathrm{O}\right)$ in deionized distilled water (DDW). $\mathrm{Ni}(\mathrm{II})$ solutions of different concentrations were prepared by adequate dilution of stock solution with DDW. All the glassware and polypropylene flasks to be used in experiments were overnight immersed in $10 \%(\mathrm{v} / \mathrm{v}) \mathrm{HNO}_{3}$ and rinsed several times with DDW. Before and after the experiments $\mathrm{Ni}(\mathrm{II})$ contents in the solutions were determined by flame atomic absorption spectrometry (FAAS), using Shimadzu 6800 atomic absorption spectrophotometer equipped with an air-acetylene flame and controlled by Intel personal computer. The hollow cathode lamp was operated at $12 \mathrm{~mA}$ and analytical wavelength was set at $232 \mathrm{~nm}$.

\section{Batch Biosorption Experiments}

The affinity of biomass to adsorb Ni(II) ions was studied in batch experiments. In all sets of experiments, fixed volume of $\mathrm{Ni}(\mathrm{II})$ solution $(100 \mathrm{~mL})$ was stirred with desired biosorbent dose $\left(10 \mathrm{~g} \mathrm{~L}^{-1}\right)$ of 50 mesh size at $33 \pm 1^{\circ} \mathrm{C}$ and $200 \mathrm{rpm}$ for 1 hour. Different conditions of $\mathrm{pH}(1,2,3,4,5$, $6,7)$, initial metal concentration $\left(500,300,200,100,50,25,10 \mathrm{mg} \mathrm{L}^{-1}\right)$ and contact time (10-90 with 10 minutes increment) were evaluated during study. In order to regulate $\mathrm{pH}$ of the medium $0.1 \mathrm{~mol} \mathrm{~L}^{-1} \mathrm{NaOH}$ and $\mathrm{H}_{2} \mathrm{SO}_{\text {, were used. }}$ The $250 \mathrm{~mL}$ flasks were placed on an orbital rotating shaker with constant shaking rate for the periods mentioned above. The solutions were separated 
from biomass by filtration through Whatman 40 filter paper. For the sorption time of $1 \mathrm{hr}$ equilibrium on $\mathrm{Ni}(\mathrm{II})$ uptake was achieved. The amount of $\mathrm{Ni}(\mathrm{II})$ uptake was calculated by difference in concentration. The initial concentration $\mathrm{C}_{\mathrm{i}}\left(\mathrm{mg} \mathrm{L}^{-1}\right)$ and metal concentrations at various time intervals, $\mathrm{C}_{f}\left(\mathrm{mg} \mathrm{L}^{-1}\right)$, were determined and the metal uptake $\mathrm{q}_{\mathrm{e}}$ (mg metal adsorbed / $\mathrm{g}$ adsorbent) was calculated from the mass balance equation given below;

$$
q_{e}=\frac{\left(C_{i}-C_{f}\right) V}{W}
$$

Where $\mathrm{V}$ is the volume of solution in ' $\mathrm{L}$ ' and $\mathrm{W}$ is the mass of sorbent in $\mathrm{g}$.

\section{RESULTS AND DISCUSSION}

Effect of contact time, $\mathrm{pH}$, initial metal concentration, biosorbent dose and temperature on Ni(II) sorption capacity of Ficus Religiosa leaves were investigated. All the experiments were repeated thrice to confirm the results and average values are presented.

\section{Effect of pH on Ni(II) sorption}

The solution $\mathrm{pH}$ has been reported to be most important variable governing the biosorption of metal ions by sorbents. In order to establish the effect of $\mathrm{pH}$ on the sorption of $\mathrm{Ni}(\mathrm{II})$ ions onto Ficus Religiosa, batch equilibrium studies at different $\mathrm{pH}$ values were carried in the range 1-7 (Fig. 1). The experiments were not conducted beyond $\mathrm{pH}=7$ due to Nickel hydroxide precipitation. It was found that uptake of free $\mathrm{Ni}$ (II) depends on $\mathrm{pH}$ and increase with increasing $\mathrm{pH}$. Similar results have been reported in literature for different metal-biomass systems $^{15,16}$.

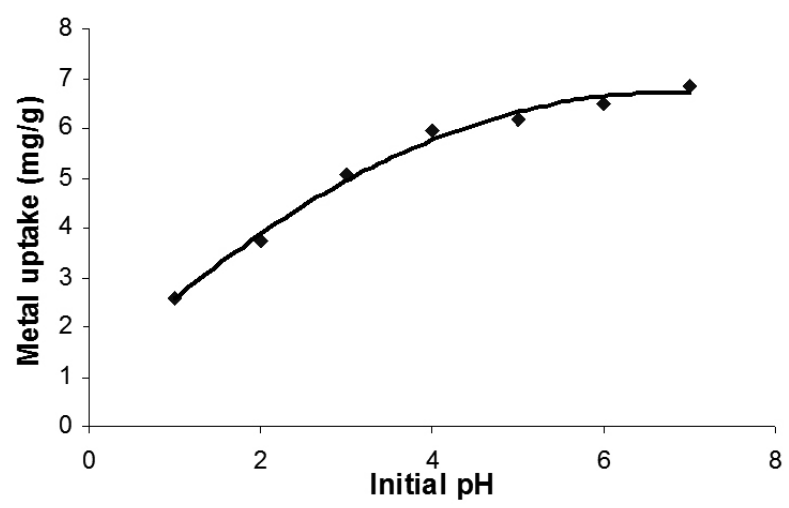

Fig. 1. Effect of initial solution $\mathrm{pH}$ on the metal uptake (Time $=1 \mathrm{hr}$, Biosorbent dose $=10 \mathrm{~g} \mathrm{~L}^{-1}$, Volume of solution $=100 \mathrm{~mL}$, Initial Concentration $=100 \mathrm{mg} \mathrm{L}^{-1}$, Temperature $=33 \pm 1^{\circ} \mathrm{C}$ ).

The diffusion of metal ions from the bulk solution to active sites of dead biomass occurs predominantly by passive transport mechanism: metal ion diffuse to the surface of biomass where they bind to active sites on the cell surface formed with various chemical groups such as carboxylate, hydroxyl, amino and phosphate that exhibit affinity for metal ions ${ }^{17}$. According to surface complexation theory the increase in metal removal as $\mathrm{pH}$ increases can be explained on the basis of a decrease in competition between proton and metal species for surface sites and by decrease in the surface charge ${ }^{18}$. At $\mathrm{pH}$ close to 5 the binding sites are negatively charged due to presence of carboxylic, hydroxyl and amino groups ${ }^{10}$ and the intensity of induced charges on the functional groups depend on how higher or lowers the $\mathrm{pH}$. That's why $\mathrm{Ni}(\mathrm{II})$ is mainly attracted by the biosorbent beyond this $\mathrm{pH}$. A decrease in $\mathrm{pH}$ was observed at the end of experiments which was probably due to release of proton as a result of ion exchange between $\mathrm{Ni}^{+2}$ and $\mathrm{H}^{+}$ions. Based on the shift of $\mathrm{pH}$ value in the biosorption process it may be concluded that ion exchange was the dominant mechanism during sorption process.

\section{Effect of Solid/Liquid Ratio on Sorption}

The effect of solid to liquid ratio on the $\mathrm{Ni}(\mathrm{II})$ sorption was studied by keeping all other parameters constant. Various ratios ranging from $1-80 \mathrm{~g}$ $\mathrm{L}^{-1}$ were used to determine the suitable quantity of biomass for maximum sorption. It is evident from the figure 2 that an adsorbent dose of $10 \mathrm{~g} \mathrm{~L}^{-1}$ is sufficient for the removal of metal. Further increment in sorbent dose did not cause significant improvement in the sorption. The removal capacity was low at high dose rate and vice versa. This was due to metal concentration shortage in solution at high dose rates.

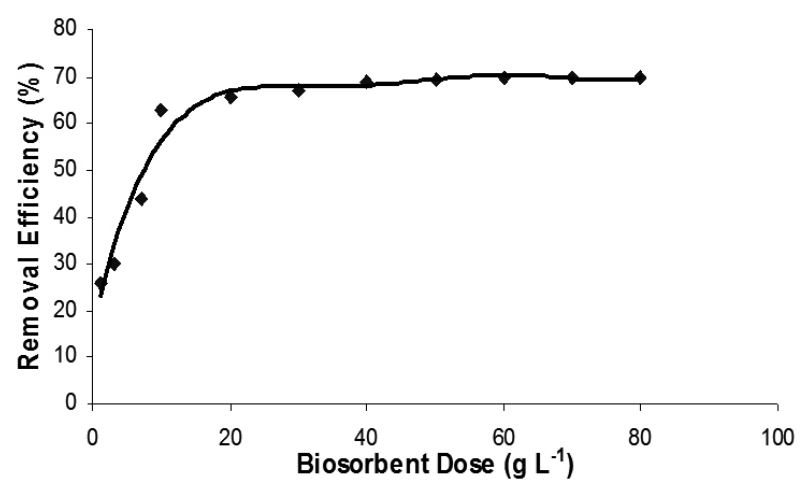

Fig. 2. Effect of adsorbent dose on \% removal of Nickel. (Time $=1 \mathrm{hr}$, $\mathrm{pH}=5.6$, Volume of solution $=100 \mathrm{~mL}$, Initial Concentration $=100 \mathrm{mg} \mathrm{L}^{-1}$, Temperature $=33 \pm 1^{\circ} \mathrm{C}$ ).

\section{Determination of Equilibrium Time}

Equilibrium time is the maximum time taken by the sorption experiment to achieve equilibrium after which no further metal uptake is observed. It can be noticed from the figure 3 that contact time significantly affects the metal uptake; the metal sorption increases sharply in first 60minutes and then tapers off thereafter, as the equilibrium approached. The relatively rapid nickel uptake indicates that the sorption process occurs mainly on the surface of biosorbent. The uptake of heavy metal ions by biosorbent has often been observed to occur in two stages: (i) rapid and quantitatively predominant and (ii) slower and quantitatively insignificant. The rapid stage is probably due to abundant availability of active sites on the biomass. With gradual occupancy of these sites, the sorption becomes less efficient in slower stages ${ }^{19}$. According to the results, it was concluded that one hour was sufficient for the sorption to attain equilibrium. The equilibrium capacity obtained after one hour of sorption was $6.35 \pm 0.54 \mathrm{mg} / \mathrm{g}$ for $\mathrm{Ni}(\mathrm{II})$.

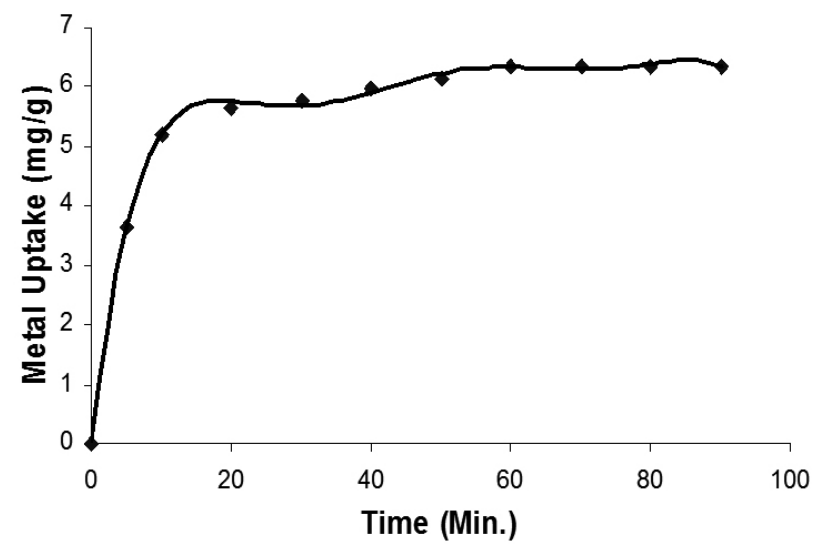

Fig. 3. Equilibrium time for nickel biosorption $(\mathrm{pH}=5.6$, Biosorbent amount $=10 \mathrm{~g} \mathrm{~L}^{-1}$ Volume of solution $=100 \mathrm{~mL}$, Initial Concentration $=100 \mathrm{mg}$ $\mathrm{L}^{-1}$, Temperature $=33 \pm 1^{\circ} \mathrm{C}$ ).

\section{Effect of Initial Metal Concentration}

The rate of sorption is a function of initial concentration of metal ions, which makes it an important factor to be considered for effective biosorption. The initial concentration provides an important driving force to overcome mass transfer resistances of metal ions between aqueous and solid phase. The initial concentration was changed in the range of $10-500 \mathrm{mg} \mathrm{L}^{-1}$ by keeping all other parameters constant (Fig. 4). At low concentrations, adsorption sites took up the available metal more quickly. However, at higher concentration, metal ions need to diffuse to the biomass surface by interparticle diffusion and greatly 
hydrolyzed ions are likely to diffuse at slower rate ${ }^{20}$. Thus sorption capacity increased with increase in initial metal ion concentration for $\mathrm{Ni}(\mathrm{II})$ on sorbent.

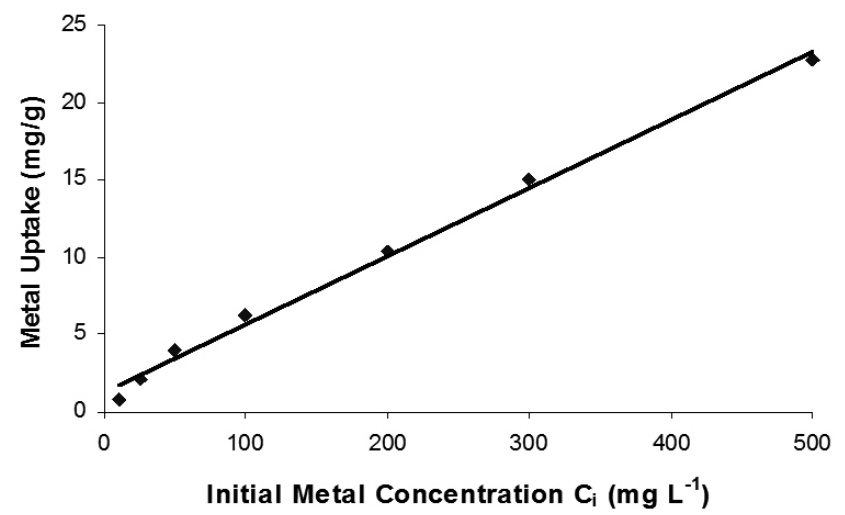

Fig. 4. Effect of initial metal concentration on biosorption of Nickel $\left(\mathrm{pH}=5.6\right.$, Biosorbent amount $=10 \mathrm{~g} \mathrm{~L}^{-1}$ Volume of solution $=100 \mathrm{~mL}$, Temperature $=33 \pm 1^{\circ} \mathrm{C}$ ).

\section{Effect of Solution Temperature}

The equilibrium uptake of $\mathrm{Ni}$ (II) on the biomass is affected by temperature change. By keeping all the other parameters constant temperature was varied from 20 to $40^{\circ} \mathrm{C}$. At higher temperatures, texture of biomass was changed that's why temperature was limited to $40^{\circ} \mathrm{C}$. Figure 5 shows that metal uptake increases with decrease in temperature in the given experimental range.

Actually more than one binding sites were available for the metal binding onto biomass. The effect of temperature on each site is different and contributes to overall uptake. The decrease of equilibrium uptake capacity with increase in temperature may be due to reason that biosorption process of $\mathrm{Ni}$ (II) metal ion by Ficus Religiosa leaves was exothermic. This is in confirmation to results that has been reported for other metals on the same biomass ${ }^{10}$.

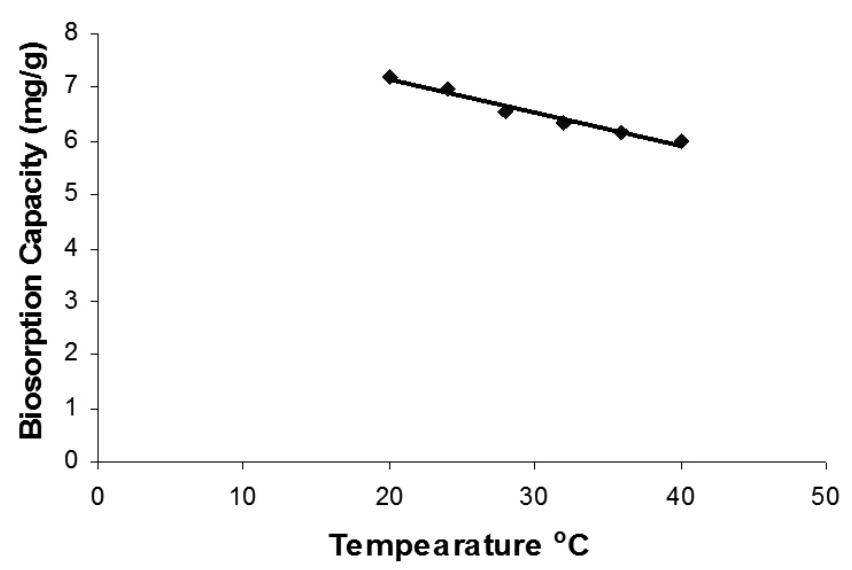

Fig. 5. Effect of Temperature on the sorption capacity of Nickel. $(\mathrm{pH}=5.6$, Biosorbent amount $=10 \mathrm{~g} \mathrm{~L}^{-1}$ Volume of solution $=100 \mathrm{~mL}$, Time $=1 \mathrm{hr}$, initial concentration $=100 \mathrm{mg} \mathrm{L}^{-1}$ ).

\section{Sorption Isotherm Models}

Modeling the equilibrium data is a fundamental for the industrial application of biosorption since it gives information for designing and optimizing operating procedure. It is also helpful in comparing different biomaterials under different operating conditions. To find the relationship between aqueous concentrations $\left(\mathrm{C}_{\mathrm{e}}\right)$ and sorbed quantity $\left(\mathrm{q}_{\mathrm{e}}\right)$ at equilibrium, mostly sorption isotherm models are used for fitting the data. Langmuir and Freundlich isotherm models are widely used. The main reason for the extended use of these isotherm models is that they incorporate constants that are easily interpretable. Langmuir Parameters can be determined from a linearized form of equation given below:

$$
\frac{\mathbf{C}_{\mathbf{e}}}{\mathbf{q}_{\mathbf{e}}}=\frac{1}{\mathbf{q}_{\mathbf{m a x}} \mathbf{b}}+\frac{\mathbf{C}_{\mathbf{e}}}{\mathbf{q}_{\mathbf{m x}}}
$$

Where ' $\mathrm{q}_{\mathrm{e}}$ ' is the metal ion sorbed $(\mathrm{mg} / \mathrm{g}), \mathrm{C}_{\mathrm{e}}$ the equilibrium concentration of metal ion solution, $\mathrm{q}_{\max }$ and ' $\mathrm{b}$ ' are Langmuir constants. The Langmuir constant ' $q$ ' ' defined as the amount of adsorbate per unit weight of adsorbent to form a complete monolayer on a sorbate surface was found to be $25.71 \mathrm{mg} / \mathrm{g}$, while, ' $b$ ' which reflects quantitatively the affinity between the adsorbent and adsorbate was equal to $0.0129 \mathrm{~L} / \mathrm{mg}$. Lower value corresponds to more affinity of metal to biomass ${ }^{10}$.

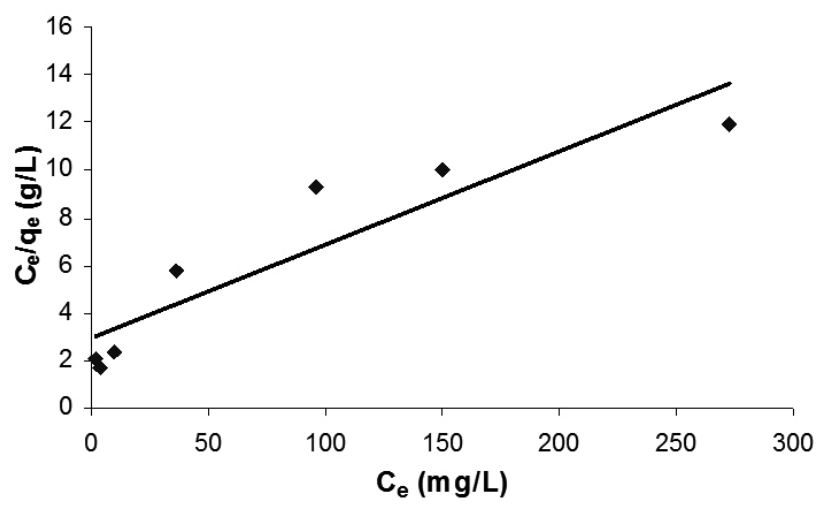

Fig. 6. Langmuir plot for nickel biosorption

The Freundlich Model is expressed as:

$$
\mathbf{q}_{\mathbf{e}}=\mathbf{K}_{\mathbf{F}} \mathbf{C}_{\mathbf{e}}^{1 / \mathbf{n}}
$$

Above equation can be rearranged into following form:

$$
\ln \mathbf{q}_{\mathbf{e}}=\ln \mathbf{K}_{\mathbf{F}}+\frac{1}{\mathbf{n}} \ln \mathbf{C}_{\mathbf{e}}
$$

$\mathrm{q}_{\mathrm{e}}$ is metal ion sorbed $(\mathrm{mg} / \mathrm{g}), \mathrm{C}_{\mathrm{e}}$ the equilibrium concentration of metal ion solution $\left(\mathrm{mg} \mathrm{L}^{-1}\right)$, ' $\mathrm{K}_{\mathrm{F}}$ ' and ' $\mathrm{n}$ ' are Freundlich constants. The constants $\mathrm{K}_{\mathrm{F}}$ and $1 / \mathrm{n}$ were determined by linear regression from the plot of $\ln \mathrm{q}_{\mathrm{e}}$ against $\log$ $\mathrm{C}$. $\mathrm{K}$ is a measure of the degree or strength of adsorption, while $1 / \mathrm{n}$ is used as an indication of whether adsorption remains constant $($ at $1 / n=1)$ or decreases with increasing adsorbate concentrations (with $\left.1 / \mathrm{n}^{1} 1\right)^{9}$.

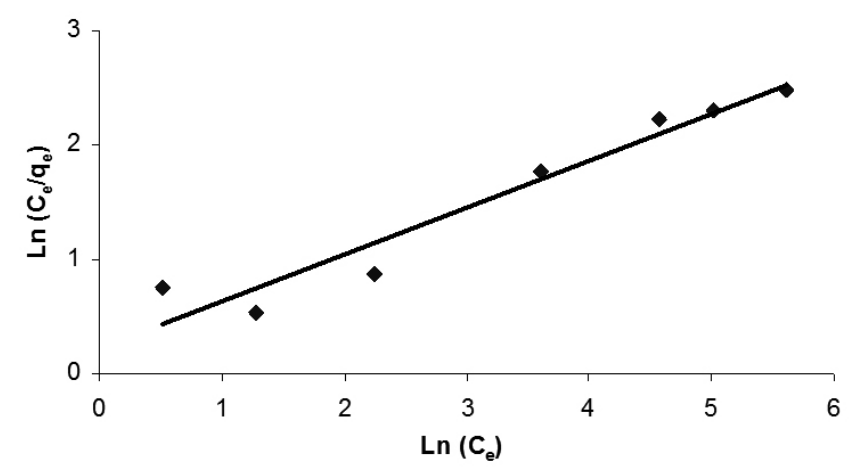

Fig. 7. Freundlich plot for nickel biosorption

It appears that Freundlich (Fig. 7) model best fits the experimental results than Langmuir (Fig. 6) over the experimental range with good correlation $\left(\mathrm{R}^{2}=0.94\right)$ co-efficient. Model constants of both Langmuir and Freundlich along with correlation co-efficient values are listed in table 1 . 
Table 1: Isotherm Constants for Ni(II) Sorption onto Ficus Religiosa Leaves

\begin{tabular}{|l|c|c|}
\hline \multicolumn{2}{|c|}{ Langmuir isotherm parameters } & \multicolumn{2}{c|}{$\begin{array}{c}\text { Freundlich isotherm } \\
\text { parameters }\end{array}$} \\
\hline $\mathrm{q}_{\max }(\mathrm{mg} / \mathrm{g})=$ & 25.71 & $\mathrm{~K}_{\mathrm{F}}(\mathrm{mg} / \mathrm{g})=1.25$ \\
$\mathrm{~b}(\mathrm{~L} / \mathrm{mg})=$ & 0.0129 & $\mathrm{n}=2.44$ \\
$\mathrm{R}^{2}=$ & $\mathrm{R}^{2}=0.95$ \\
\hline
\end{tabular}

\section{Kinetic Modeling}

Kinetic models have been used to test the experimental data to investigate about mechanism of biosorption and potential rate controlling step, such as mass transfer and chemical reaction processes. The transient behavior of batch biosorption process was analyzed using the second-order kinetic model.

The pseudo second-order model considers that the rate of occupation of biosorption sites is proportional to the square of the number of unoccupied $\operatorname{sites}^{21}$.

$$
\frac{d q_{t}}{d t}=k\left(q_{e q}-q_{t}\right)^{2}
$$

Where $\mathrm{t}(\mathrm{min})$ shows time, $\mathrm{q}_{\mathrm{t}}(\mathrm{mg} / \mathrm{g})$ shows uptake capacity at $\mathrm{t}$ and $\mathrm{k}$ $\left(\mathrm{g} \mathrm{mg}^{-1} \mathrm{~min}^{-1}\right.$ ) shows the equilibrium rate constant of pseudo-second order adsorption. After being integrated and rearranged

$$
\frac{t}{d t}=\frac{1}{k q_{e q}^{2}}+\frac{t}{q_{e}}
$$

The sorption coefficient ' $\mathrm{k}$ ' and equilibrium capacity ' $\mathrm{q}_{\mathrm{e}}$ ' can be determined from the linear plot (Fig. 8) of $\mathrm{t} / \mathrm{q}_{\mathrm{t}}$ versus t. The coefficient of correlation $\left(\mathrm{R}^{2}=\right.$ $0.9994)$ for the kinetic model was approximately to one at given temperature and estimated values $\left(\mathrm{q}=6.63 \mathrm{mg} / \mathrm{g}\right.$ and $\left.\mathrm{k}=0.0408 \mathrm{~g} \mathrm{mg}^{-1} \mathrm{~min}^{-1}\right)$ of $\mathrm{q}$ also agreed with experimental ones. Both facts suggests that sorption of $\mathrm{Ni}(\mathrm{II})$ ions follows the second order kinetic model which relies on the assumption that biosorption may be the kinetic controlled. The obtained kinetic result has a significant practical worth for the technological applications, since the kinetic modeling successfully replaces time and material consuming experiments, necessary for the process equipment design ${ }^{22}$.

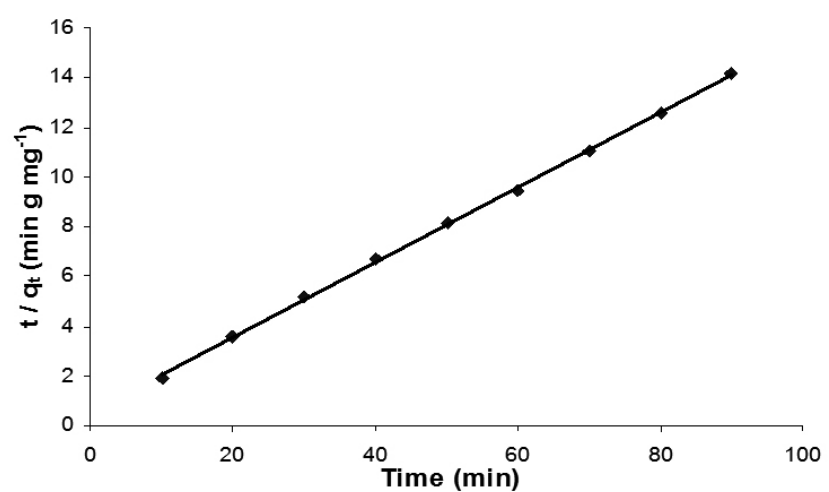

Fig. 8: Linearized pseudo-second order biosorption kinetics of Nickel (II)

\section{CONCLUSIONS}

The effect of different factors on the sorption abilities of inexpensive agro-based waste material was studied for the removal of $\mathrm{Ni}$ (II) from aqueous solution. The following conclusion can be drawn from the present study.

1. Ficus Religiosa leaves is the suitable material for $\mathrm{Ni}(\mathrm{II})$ biosorption.

2. $\mathrm{pH}$, biomass dose, temperature, initial metal concentration, and contact time highly affect the overall metal uptake capacity of biosorbent.

3. The sorption was $\mathrm{pH}$ dependant and sorption capacity increased with increase in $\mathrm{pH}$ value for the examined $\mathrm{pH}$ range. And main removal mechanism of $\mathrm{Ni}$ (II) is ion exchange between proton of active sites and metal cations.

4. The optimum time was observed to be $1 \mathrm{hr}$ with sorption capacity of $6.35 \pm 0.54 \mathrm{mg} / \mathrm{g}$. and Optimum dosage was $10 \mathrm{~g} \mathrm{~L}^{-1}$.

5. Present results show that Freundlich model fits better than Langmuir model for the adsorption equilibrium data in the examined concentration range (10- $\left.500 \mathrm{mg} \mathrm{L}^{-1}\right)$.

6. Biosorption of nickel was favorable at lower temperature and the kinetics of biosorption process was represented well by pseudo $2^{\text {nd }}$ order kinetic model.

\section{ACKOWLEDGEMENT}

The support of Department of Chemical Engineering, University of Engineering and Technology Lahore is highly appreciated.

\section{REFERENCES}

1. M. Işik, Colloid Surface B. 62, 97, (2008)

2. D. Sud, G. Mahajan, M.P. Kaur, Bioresource Technol. 99, 1, (2008).

3. U.K. Garg, M.P. Kaur, D. Sud, J Hazard Mater. 140, 60, (2006).

4. L. Zhang, L. Zhao, Y. Yu, C. Chen, Water Res. 32, 1437, (1998).

5. J. Wang, C. Chem, Biotechnol Adv. 24, 427, (2006).

6. H. Eccles, Int Biodeter Bioegr. 5, 1995.

7. V. Padmovathy, P. Vasudevan, S.C. Dhingra, Process Biochem. 38, 1389, (2003).

8. GSR 801 (E), EPA, 1986, dated Dec. 31, 1993.

9. M. A. Hanif, R. Nadeem, M. A. Zafar, K. Akhtar, H.N. Bhatti, J Hazard Mater. 139, 345, (2007).

10. S. Qaiser, A. R. Saleemi, M. M. Ahmad, Electron J Biotecnol. 10, 409, (2007).

11. A. Demirbas, J Hazard Mater. 1, (2008).

12. D. D. Adrian, et. al, Water Res. 33, 2469, (1999).

13. G. Cimino, A. Passerini, G. Toscano, Water Res. 34, 2955, (2000).

14. N. A. A. Babaninde, J Pur Appl Sci. 5, 81, (2000).

15. N. C. M. Gomes, V. R. Linardi, Rev Microbiol. 27, 218, (1996).

16. J. L. Zhou, P. L. Huang, R. G. Lin, Environ Pollut. 101, 67, (1998).

17. A. Ozer, D. Ozer, J Hazard Mater. 100, 219, (2003).

18. Y. Sag, D. Ozer, T. Kutsal, Process Biochem. 30, 169, (1995).

19. S. Basha, Z. V. P. Murthy, B. Jha, Chem Eng J.1, (2008).

20. H. M. Jnr, I. A. Spiff, Electron J Biotecnol. 4,191,(2004).

21. G. Mckay, Y. S. Ho, J. C. Y. Ng, Separ Purif Method. 29(2), 189, (2000).

22. M. X. Loukidou, A. I. Zouboulis, T. D. Karapantsios, K. A. Matis, Colloid Surface A. 242, 93, (2004). 